\title{
Cyclic adenosine monophosphate (cAMP) production in avian theca cells during follicular maturation*
}

\author{
B. L. Marrone† and E. K. Asem $\ddagger$ \\ Department of Obstetrics and Gynecology, St Louis University School of Medicine, St Louis, \\ MO 63104, U.S.A.
}

\begin{abstract}
Summary. LH was used to stimulate cAMP production in theca cells from the 5 largest preovulatory follicles of hens and this was related to $\mathrm{LH}$-stimulated androstenedione production in the same cells. cAMP production was stimulated by LH to the same extent in theca cells from each follicle. However, $\mathrm{LH}$ was not effective in stimulating androstenedione production in theca cells from the largest follicle (T1), although androstenedione production was greatly increased by LH in the smaller follicles (T2-T5). Effects similar to those of LH on CAMP production were observed in response to forskolin, indicating that the intrinsic adenylate cyclase activity was similar in theca cells from each follicle. In addition, forskolin was unable to stimulate androstenedione production by $\mathrm{T} 1$ cells. Our results provide evidence that the levels of receptormediated and non-receptor-mediated cAMP production are similar in theca cells from the 5 largest follicles. We conclude that the step that restricts the ability of $\mathrm{T} 1$ cells to produce androgen is distal to cAMP generation.
\end{abstract}

Keywords: cAMP; theca; LH; follicular maturation; domestic hen

\section{Introduction}

Oestrogen and androgen production by the large yolk-filled preovulatory follicles of the hen occurs in the theca cells and is influenced by LH and the stage of maturation (Huang et al., 1979; Marrone \& Hertelendy, 1983a, b, 1985; Armstrong, 1984). During the immediate preovulatory period (Marrone \& Hertelendy, 1983a, 1985) and at 15-16 h before ovulation (Huang et al., 1979) LHstimulated oestrogen and androgen production is greatest in theca cells from the third (T3) and fourth (T4) largest follicle and minimal in theca cells from the largest follicle destined to ovulate next. The reduction in oestrogen and androgen production in $\mathrm{T} 1$ cells can be attributed directly to decreased aromatase activity (Huang et al., 1979; Marrone \& Hertelendy, 1983a; Armstrong, 1984) and decreased C17-20-lyase activity (Marrone \& Hertelendy, 1985) in these cells, respectively, when provided with the appropriate substrate.

In the present study, we investigated whether early events in the pathway of LH receptormediated steroidogenesis in hen theca cells were influenced by the stage of follicle development in a manner that paralleled the changes in aromatase and C17-20-lyase activities.

\footnotetext{
*Reprint requests to B. L. Marrone.

†Present address: Los Alamos National Laboratory, Life Sciences Division, Mail Stop: M888, Los Alamos, NM 87545, U.S.A.

$\ddagger$ Present address: University of Ottawa Civic Hospital, Dept. of Obstetrics \& Gynecology, Reproductive Biology Unit, 1053 Carling Ave., Ottawa, Ontario, Canada, K1Y 4E9.
} 


\section{Materials and Methods}

Experimental animals. White Leghorn laying hens were obtained from the University of Missouri, Columbia, or from Ralston Purina Farms, Gray Summit, MO. They were individually housed in cages in a windowless room under a $14 \mathrm{~h}$ light $/ 24 \mathrm{~h}$ cycle with lights on at $06: 00 \mathrm{~h}$. They received Purina Layena ration and water ad libitum. The times of oviposition were recorded by automatic devices. The birds selected for this study had oviposited daily for at least 5 consecutive days.

Hormones and chemicals. The 3',5'-cyclic AMP, 3-isobutyl-1-methylxanthine (IBMX), androstenedione, collagenase type 1, bovine serum albumin (BSA, Fraction V), and Hepes were purchased from Sigma Chemical Co. (St Louis, MO). Ovine LH (NIADDKD-LH-22, 2.3 NIH-LH-SI U/mg) was the generous gift of the National Hormone and Pituitary Program of the National Institutes of Health. The LH was reported to contain $<0.5 \% \mathrm{FSH}$. Ficoll 400 was obtained from Pharmacia Fine ( hemicals (Piscataway, NJ) and powdered Medium 199 (M199, with Hanks' salts and L-glutamate) was purchased from Gibco Laboratories (New York, NY). Hepes (10 mM), $0.1 \%$ BSA and sodium bicarbonate were combined with the powder to form the culture medium ( $\mathrm{pH} 7 \cdot 4)$. The cell-washing medium (CMF) was calcium- and magnesium-free phosphate-buffered $0.9 \%(\mathrm{w} / \mathrm{v}) \mathrm{NaCl}$ that contained $0.2 \%$ glucose. Androstenedione antiserum (ANS-22) was purchased from Endocrine Sciences (Tarzana, CA) and the cAMP antiserum was the generous gift of Dr G Brooker (Department of Pharmacology, University of Virginia School of Medicine, Charlottesville, VA, 22908, U.S.A.). $\left[1,2,6,7-{ }^{3} \mathrm{H}\right]$ Androstenedione (sp. act. $80-115 \mathrm{Ci} / \mathrm{mmol}$ ) and ${ }^{125} \mathrm{I}$-labelled cyclic AMP (sp. act. $3010 \mathrm{Ci} / \mathrm{g}$, carrier-free) were purchased from New England Nuclear Corp. (Boston, MA).

Tissue collection and cell preparation. The birds were killed by cervical dislocation $2-4 \mathrm{~h}$ before expected ovulation, as in previous experiments (Marrone \& Hertelendy, 1983a, b, 1985). The 5 largest yolk-filled follicles were removed, the theca and granulosa layers were separated completely, and cells were isolated from the theca layer by collagenase digestion and washed as described previously (Marrone \& Hertelendy, 1983a, b, 1985). The theca tissue is highly vascularized, and we were concerned that cAMP produced by red blood cells in the theca cell preparation would interfere with our ability to detect theca cell-derived cAMP. Therefore, in an effort to reduce the number of red blood cells in the theca cell preparation, the cells in a total volume of $600 \mu \mathrm{l} \mathrm{CMF}$ were layered on a cushion of $20 \%$ Ficoll in $\mathrm{CMF}$ and centrifuged at $400 \mathrm{~g}$ for $15 \mathrm{~min}$ (Freshney, 1987). A broad band of theca cells was removed from the interface of the medium and Ficoll, with care taken to avoid collecting the adjacent band of red blood cells. The isolated theca cells were washed 3 times with M199 and counted with the aid of a haemocytometer. In general, the Ficoll separation step reduced the number of red blood cells to about the number of theca cells in each preparation. Theca cell viability was determined by exclusion of $0.01 \%$ trypan blue and was at least $90 \%$ in all cases.

Incubations. Incubations were done in borosilicate glass culture tubes in a shaking water bath, open to the air, at $37^{\circ} \mathrm{C}$. There were 5 replicate tubes per treatment group and $1 \times 10^{5}$ theca cells from each follicle were added to $10 \times 75 \mathrm{~mm}$ culture tubes containing $0.1 \mathrm{mM}$-IBMX and preincubated for $30 \mathrm{~min}$. The agonists were added and cells were incubated for $3 \mathrm{~h}$ in a total volume of $0.5 \mathrm{ml} \mathrm{M} 199$. The incubation was terminated by placing the tubes in an ice-water bath. The samples were kept frozen at $-60^{\circ} \mathrm{C}$ until assayed.

Radioimmunoassays. The androstenedione radioimmunoassay was done on diethyl ether extracts of the cells and media as described previously, and the cross-reactivity of the antiserum, parallelism, inter- and intra-assay coefficients of variation (CV), and sensitivity of the assay have been reported (Marrone \& Hertelendy, 1985). Inter- and intraassay CVs were each about $10 \%$; the sensitivity of the assay was $10 \mathrm{pg}$. Parts $(1-10 \%)$ of the sample extracts redissolved in ethanol were used in the androstenedione radioimmunoassay. The cAMP radioimmunoassay was done on acetylated aliquants of the cells and media as described previously, using the method and antiserum of Brooker et al. (1979). The assay details and validation have been reported (Asem \& Hartelendy, 1983). Inter- and intra-assay $\mathrm{CVs}$ were each about $13 \%$; the sensitivity of the assay was $10 \mathrm{fmol}$. For both the androstenedione and cAMP radioimmunoassays, all relevant comparisons were analysed in the same assay.

Data analysis. All comparisons were done on fold-increases of stimulated $v s$ unstimulated values of cAMP or androstenedione. Comparisons involving two groups were done by paired $t$ tests. Comparisons amongst follicles were done by repeated measures analysis of variance (ANOVA). Probability levels of $<0.05$ were considered statistically significant. Statistical analyses were done on results combined from 5-6 separate experiments.

\section{Results}

\section{Experiment I}

LH-stimulated androstenedione and cAMP production were assessed in the same cell populations of theca cells isolated from the 5 largest follicles. The dose of $\mathrm{LH}$ used $(250 \mathrm{ng} / \mathrm{ml})$ was maximally stimulating in terms of androstenedione production in theca cells (preliminary experiments; data not shown). LH induced significant (10-to 18-fold) increases in cAMP production in theca cells from each follicle $(P<0.05 ; t$ tests; Fig. 1a). Repeated measures ANOVA across T1 to T5 indicated that 


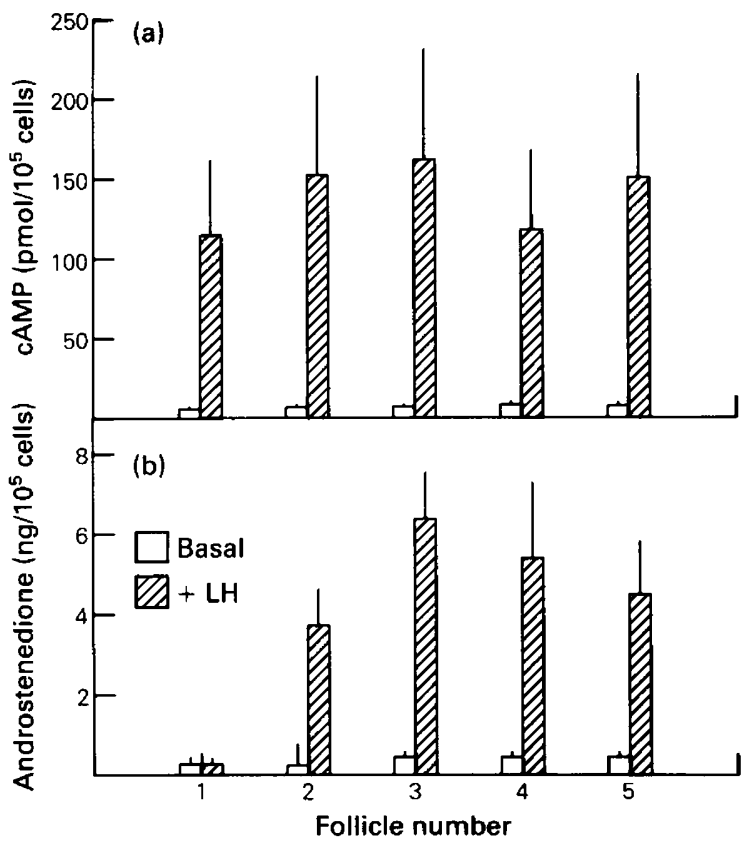

Fig. 1. Effect of LH (250 ng/ml) on production of (a) CAMP and (b) androstenedione by theca cells from the largest (1), second largest (2), third largest (3), fourth largest (4), and fifth largest (5) preovulatory follicles of hens. Values are mean \pm s.e.m. for 6 independent experiments.

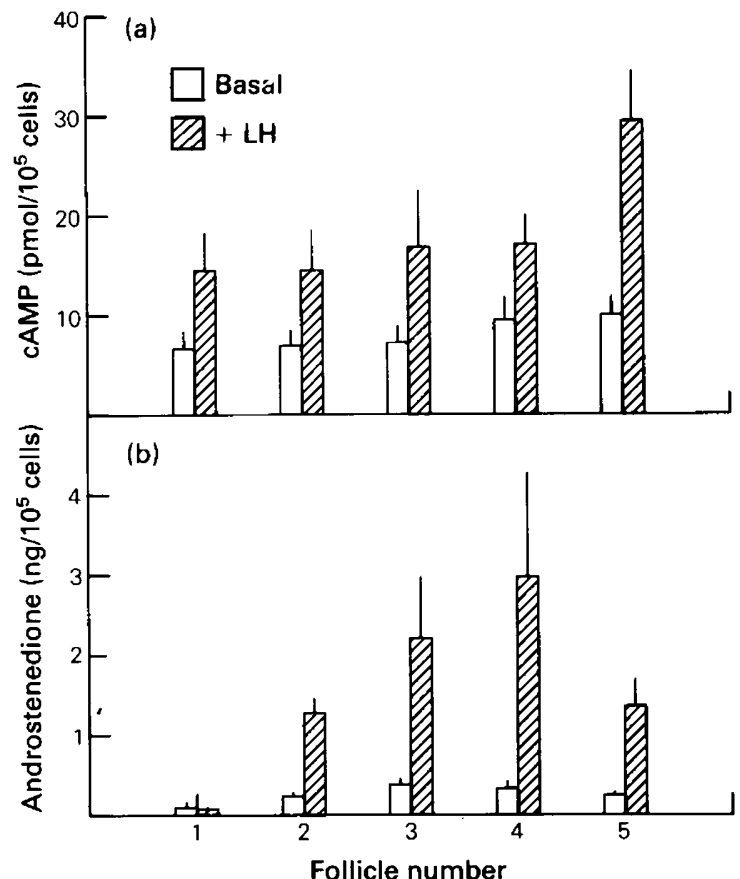

Fig. 2. Effect of forskolin (1-10 $\mu \mathrm{M})$ on the production of (a) cAMP and (b) androstenedione by theca cells from the largest (1), second largest (2), third largest (3), fourth largest (4), and fifth largest (5) preovulatory follicles of hens. Values are mean \pm s.e.m. for 5 independent experiments. 
the fold-increases in levels of cAMP production were not significantly different in T1-T5 cells. By comparison, $\mathrm{LH}$ stimulation had no effect on androstenedione production in T1 cells but induced significant (16- to 17-fold) increases in androstenedione production in T2-T 5 cells $(P<0.05$; $t$ tests; Fig. 1b). A repeated measures ANOVA comparing fold-increases in androstenedione across $\mathrm{T} 1$ to T5 was significant $(P<0.005)$.

\section{Experiment 2}

Androstenedione and cAMP production were measured in response to forskolin, which stimulates adenylate cyclase in a non-receptor-mediated manner, in the same population of theca cells from the 5 largest follicles. A low dose of forskolin $(1-10 \mu \mathrm{mol})$ significantly increased cAMP production by 2- to 3-fold in theca cells from each of the 5 largest follicles, including $\mathrm{T} 1$ cells $(P<0.05, t$ tests; Fig. 2a). A repeated measures ANOVA on fold-increases in cAMP levels among T1-T5 cells showed no significant differences between follicles. By comparison, androstenedione production was not increased by forskolin in T1 cells but was increased significantly by 3-6-fold in response to forskolin in T2 to T5 cells $(P<0.05, t$ tests; Fig. 2b). A repeated measures ANOVA performed on fold-increases in androstenedione across T1 to T5 was significant $(P<0.025)$.

\section{Discussion}

Our results showed that both hormonally stimulated and intrinsic cAMP production were not different in theca cells from the 5 largest preovulatory follicles. Although we cannot rule out the possibility that the red blood cells that contaminated the theca cell preparations did not contribute to basal or forskolin-stimulated levels of cAMP, it is highly unlikely that they contributed to $\mathrm{LH}$ stimulated cAMP production. By comparison, androstenedione production in response to $\mathrm{LH}$ or forskolin was stimulated in T2-T5 cells, but not in T1 cells.

In a previous study using high-performance liquid chromatography to analyse steroid metabolism we demonstrated that C17-20-lyase activity, as measured by conversion of $\left[{ }^{3} \mathrm{H}\right] 17$ hydroxyprogesterone to androstenedione, was deficient in T1 cells (Marrone \& Hertelendy, 1985). Furthermore, there was no evidence that the decreased accumulation of androstenedione in $\mathrm{T} 1$ cells was due to an enhanced metabolism of androstenedione to other metabolites. In other studies, aromatase activity, as indicated by decreased conversion of testosterone to oestrogen, was also found to be greatly decreased in T1 cells (Huang et al., 1979; Marrone \& Hertelendy, 1983a; Armstrong, 1984). Taken together, these findings indicate that cAMP production does not limit steroidogenesis in $\mathrm{T} 1$ cells and that specific decrements in C17-20-lyase and aromatase activities can account for the impaired androgen and oestrogen production, respectively, of $\mathrm{T} 1$ cells.

This is the first report of cAMP production in hen theca cells. Other studies have examined the adenylate cyclase activity and cAMP production of hen granulosa cells during follicular maturation. Using a cell-free system of hen granulosa layer, Calvo \& Bahr (1982) and Johnson \& Bahr (1985) have reported that gonadotrophin-stimulated and basal adenylate cyclase activity increased during follicular maturation in parallel with the increasing ability of granulosa cells to synthesize progesterone. By comparison, using intact granulosa cells, Asem \& Hertelendy (1986) found that, of the 5 largest follicles, cells from the $3 \mathrm{rd}$ and 4 th largest follicles produced the greatest amount of cAMP in response to $\mathrm{LH}$. Their results suggested that greater progesterone production by the largest follicle cannot be ascribed solely to receptor-coupled adenylate cyclase activity. In the present study, cAMP production did not parallel the changing androstenedione production in theca cells during follicular maturation. However, our finding does not rule out the possibility that cAMP production may correspond more closely to the activity of other steroidogenic systems in theca cells. For example, 20 $\beta$-hydroxysteroid dehydrogenase is a major enzyme in hen theca cells (Llewelyn, 1981; Marrone \& Hertelendy, 1983b, 1985) and its activity was shown to be similar in T3 
and Tl cells (Marrone \& Hertelendy, 1985). Likewise, the $3 \beta$-hydroxy- $\Delta^{5}$-steroid dehydrogenase enzyme remains active in $\mathrm{T} 1$ cells, although at a slightly lower level than in T2-T5 cells (Armstrong, 1982).

Therefore, in hen $\mathrm{T} 1$ cells, in which there are specific deficits in steroidogenic enzymes that occur without a reduction in $\mathrm{LH}$-stimulated cAMP production, there is a resemblance to the situation of gonadotrophin-induced desensitization described for Leydig cells. In rat Leydig cells, repeated gonadotrophin stimulation results in a loss of gonadotrophin receptors and in 'lesions' at selected steps in the steroidogenic pathway. Although gonadotrophin receptor loss accompanies the loss of steroidogenic ability, the steroidogenic lesions do not occur directly as the result of the receptor loss (Dufau et al., 1984).

In conclusion, the attenuated androgen production of theca cells isolated from the follicle destined to ovulate next occurs without a reduction in hormonally or non-hormonally stimulated cAMP production. The previously demonstrated losses of C17-20-lyase and aromatase enzyme activities may be solely responsible for the attenuated androgen and oestrogen production, respectively, of hen $\mathrm{T} 1$ cells.

We thank Dr H. Beillier (University of Missouri, Columbia) and Mr D. Stebler (Ralston Purina Research Farms, Gray Summit, MO) for the generous gifts of experimental birds; Ms W. Eleissawy for technical assistance; Dr James O'Donnell for advice on statistical analyses; and Ms Noyola Scott and Ms Ruby Archuleta for secretarial assistance. Supported by HD-21339 from the National Institutes of Health.

\section{References}

Armstrong, D.G. (1982) 3 $\beta$ - $\Delta 5$-steroid dehydrogenase activity in the rapidly growing ovarian follicles of the domestic fowl (Gallus domesticus). J. Endocr. 93, 415-421.

Armstrong, D.G. (1984) Ovarian aromatase activity in the domestic fowl. J. Endocr. 100, 81-86.

Asem, E.K. \& Hertelendy, F. (1983) Effects of forskolin on progesterone and cyclic adenosine monophosphate production in avian granulosa cells. Biol. Reprod. 29, 1098-1104.

Asem, E.K. \& Hertelendy, F. (1986) Steroidogenesis and cAMP production in isolated avian granulosa cells during follicular maturation: Lack of positive correlation. Acta endocr., Copenh. 113, 289-297.

Brooker, G., Harper, J.F., Terasaki, W.L. \& Moylan, R.D. (1979) Radioimmunoassay of cyclic AMP and cyclic GMP. Adv. cyclic Nucleotide Res. 10, 1-33.

Calvo, F.O. \& Bahr, J.M. (1982) Hormone stimulable adenylyl cyclase system in the granulosa cells of the domestic hen (Gallus domesticus). Gen. comp. Endocrinol. 48, 452-461.

Dufau, M.L., Winters, C.A., Hattori, M., Aquilano, D., Baranao, J.L.S., Nozu, K., Baukal, A. \& Catt, K.J. (1984) Hormonal regulation of androgen production by the Leydig cell. J. steroid Biochem. 20, 161-173.

Freshney, R.I. (1987) Culture of Animal Cells, 2nd edn. Alan R. Liss, Inc., New York.
Huang, E.S., Kao, K.J. \& Nalbandov, A.V. (1979) Synthesis of sex steroids by cellular components of chicken follicles. Biol. Reprod. 20, 454-461.

Johnson, P.A. \& Bahr. J.M. (1985) Relative luteinizing hormone-stimulable adenylyl cyclase of the preovulatory follicle: a predictor of ovulation in the domestic hen. Biol. Reprod. 33, 445-450.

Llewelyn, C.A. (1981) Conversion of progesterone to $20 \beta$-hydroxy-4-pregnene-3-one by the preovulatory follicle in the hen (Gallus domesticus). IRCS Med. Sci. 9, 859 .

Marrone, B.L. \& Hertelendy, F. (1983a) Steroidogenesis by avian ovarian cells: effect of luteinizing hormone and substrate availability. Am. J. Physiol. 244, E487-E493.

Marrone, B.L. \& Hertelendy, F. (1983b) Steroid metabolism by avian ovarian cells during follicular maturation. Biol. Reprod. 29, 953-962.

Marrone, B.L. \& Hertelendy, F. (1985) Decreased androstenedione production with increased follicular maturation in theca cells from the domestic hen (Gallus domesticus). J. Reprod. Fert. 74, 543-550. 